\title{
Exploring Integrated Reporting Research: Results and Perspectives
}

\author{
Alberto Romolini (Corresponding author) \\ Associate Professor in Business Administration \\ Università Telematica Internazionale Uninettuno, Italy \\ Email: a.romolini@uninettunouniversity.net
}

Silvia Fissi

Assistant Professor in Business Administration

Department of Business and Economics, University of Florence, Italy

Elena Gori

Associate Professor in Business Administration

Department of Business and Economics, University of Florence, Italy

Received: January 20, 2017 Accepted: February 14, 2017 Published: February 19, 2017

doi:10.5296/ijafr.v7i1.10630 URL: http://dx.doi.org/10.5296/ijafr.v7i1.10630

\begin{abstract}
Integrated reporting is progressively influencing corporate non-financial reporting and, more recently, scientific debate. It is a model for combining into "One Report" the various aspects of non-financial information. Scientific debate - currently in a developmental phase - shows a lack of contributions on the subject with respect to its potential importance, and the need for more robust theoretical reflection. This article sets out to explore studies of integrated reporting to date, identifying perspectives of analysis and outlining possible routes for future development. The research is exploratory in nature and investigates the dissemination and dynamics of IR studies from when the concept appeared to date by using three of the main databases for scientific publications (Science Direct, Ebsco and Scopus) and Google Scholar research engine. The analysis shows that attention to integrated reporting exploded from 2013 and that current research uses a variety of methodologies, mainly qualitative. Moreover, the article identifies some future development for the research in the integrated reporting field.
\end{abstract}


This paper provides a first comprehensive analysis of the recent literature on the integrated reporting. The results represent also a useful starting point for academics in order to reflect on the future tracks of research and in order to develop a theoretical framework for integrated reporting.

Keywords: Integrated reporting, Non-financial reporting, One report, Sustainability, Exploratory study

\section{Introduction}

For some time now, companies have been integrating their more traditional financial reporting with non-financial aspects, such as social and environmental sustainability and governance (Kolk, 2004 and 2010; Owen, 2006).

Non-financial reporting often appears in the form of addenda to traditional financial statements or, more recently, as part of stand-alone annual reports. In general, it appears that non-financial reports are almost always prepared voluntarily, to demonstrate coherence between business behavior and social and environmental sustainability (Garcìa-Sanchez et al., 2013).

This approach, however, has two weak points. The first is that both financial and nonfinancial reports are focused on the past. The second concerns the effective embedding of non-financial reporting into corporate governance (Jensen and Berg, 2012). To resolve these issues, it was suggested that financial and non-financial information be integrated into one single report (IIRC, 2013a; Institute of Directors in Southern Africa, 2009; Rossouw, 2010), considering the global aspects of corporate management. The latest development in reporting, therefore, regards the advantages of integrating financial and non-financial information into "One Report" (Eccles and Krzus, 2010). This creates an integrated report (IR) that gives a broad picture of the company, highlights the connections between management and future aims, and shows financial performance and its long-term effects on decision-making.

The International Integrated Reporting Council (IIRC) defines IR as "[...] a concise communication about how an organization's strategy, governance, performance and prospects, in the context of its external environment, lead to the creation of value over the short, medium and long term" (IIRC, 2013a; IIRC/EY, 2013). In line with the consolidated literature, the creation of value is given for the six 'capitals' (financial, manufactured, human, social, relationship, and natural), taking into account any changes in these resources (IIRC, 2013a; Kanzer, 2010; White, 2010).

IR, therefore, aims to shed light on the dynamics of value creation, showing how a business can combine inputs, business activities and outputs to create or destroy value, growing or reducing its capital (Veltri and Silvestri, 2015).

The objective of the IIRC is, in short, to develop a new reporting framework for use by companies operating in a global market in the original for-profit environment, but in future also by the public sector (Adams and Simnett, 2011; Lodhia, 2015). 


\section{Ml Macrothink}

International Journal of Accounting and Financial Reporting

ISSN 2162-3082

2017, Vol. 7, No. 1

The first integrated report was published in 2002. Since then the number of IRs published has increased significantly. However, while the question of social and environmental information has been examined in the literature, research into integrated reporting has focused mainly on theoretical analyses and single case studies (Dey and Burns, 2010; Hong, 2010; Jensen and Berg, 2012).

Yet there are many other aspects of IR to be investigated: do companies undertake IR, how do they approach its implementation and what organizational changes are needed in the initial implementation phase (Stubbs and Higgins, 2014)?

Though recent in appearance, in the past few years IR has been the subject of fast-growing research (Haller and van Staden, 2014), with contributions looking at the question from various perspectives. De Villiers et al. (2014) have noted insufficient connection between research into integrated reporting and the results already achieved for social and environmental reporting, which ought to be the theoretical base for future lines of investigation. It is important, therefore, to consider future perspectives for integrated reporting research, starting with a look at the state of current research.

This article aims to investigate scientific studies on integrated reporting, identifying analytical perspectives already adopted and outlining possible future research scenarios. To date, insufficient attention has been paid to examining scientific research already done on IR, to gain an overview of the state of the art of research.

The article is organized as follows: first, the literature on integrated reporting is reviewed; then, after presenting our research method, we discuss results of the qualitative analysis carried out into the scientific work. Lastly, we present our conclusions and discuss the limits of the work and the implications for the future.

\section{Literature Review}

In recent years, it has become more and more evident that companies should report not only on their financial performance but also on the social and environmental effects of their business activities (Cohen et al., 2012; Frìas-Aceituno et al., 2013a). Integrated reporting was created, therefore, to bring together in one single report both financial and non-financial performance. The context was that of the global financial crisis, which saw stakeholders exerting growing pressure for corporate transparency and information regarding environmental resources. Increasingly, these elements had to be integrated into a corporate communications and reporting strategy (Higgins et al., 2014).

The first experiences of integrating financial and non-financial information date from the beginning of our century when Novozymes produced the first IR in 2002. Other European and American companies followed suit (e.g. Aviva, Coca Cola, Novo Nordisk, Pfizer) (Sierra-Garcìa et al., 2015).

In the same period, in South Africa, the first version of the King Report on corporate governance was being developed. The 2009 version suggested the need for integrated reporting by companies on governance, strategy and sustainability. In other words, King III 
(Institute of Directors in Southern Africa, 2009) decreed that strategy, risk, performance and sustainability should be "inseparable" and reported in one single IR (Rensburg and Botha, 2014).

Further pressure to develop IR then came from various sources, such as the academic world, auditors and various interest groups (Eccles et al., 2010; Eccles and Krzus, 2010; FrìasAceituno et al., 2013a). More recently in Europe, too, several countries have addressed integrated reporting. Denmark, for example, requires public companies to publish IRs. In France, firms with over 500 employees must include non-financial information in their annual reports (Eccles and Ambrester, 2011; Sierra-Garcìa et al., 2015).

In 2011 the IIRC published a discussion paper identifying the principles underlying the preparation of an IR: strategy focus, connectivity of information, future orientation, responsiveness and stakeholder inclusiveness and conciseness, and reliability and materiality (IIRC, 2011).

The model proposed by the IIRC "brings together the material information about an organization's strategy, governance, performance and prospects, reflects the commercial, social and environmental context within which it operates" (IIRC, 2011, p. 6).

The aim of an IR is to provide better reporting on corporate value creation from a short, medium and long-term perspective. Firms must report on all resources used for their activity. The IIRC calls these resources "capitals" and identifies six of them: financial, manufactured, intellectual, human, social and relationship, and natural (IIRC, 2013a). The IR should describe the business model adopted and how this integrates with the six capitals in a future perspective. It should not be simply a report of events past (Cheng et al., 2014).

Some scholars have noted how this new form of reporting has grown rapidly in importance, partly because of the numerous advantages brought by its application (Frìas-Aceituno et al., 2013b). However, compared with the potential significance of the matter, contributions have been seen as scarce, revealing numerous opportunities for research in coming years (Jensenj and Berg, 2012).

Early approaches were very varied and included theoretical and case studies (Dey and Burns, 2010; Eccles and Krzus, 2010).

De Villiers et al. (2014) note that future studies on the subject should be part of the broader debate on social and environmental reporting of which IR is the most recent development. On this point, it may be noted that early studies of IR appear sometimes disconnected from existing academic work on non-financial information. This aspect is also found in company experiences - companies taking their first steps in integrated reporting often have previous experience, sometimes of long standing, of social and environmental reporting. So they interpret IR as the future development of non-financial disclosure (Eccles et al., 2015).

Other scholars have already considered possible lines of future development for integrated reporting, identifying some potential themes. Cheng et al. (2014) found four possible areas of research connected to the importance of the information contained in the IRs for stakeholders 
and capital markets, to the contents and form of the report and to assurance. De Villiers et al. (2014) also identified as possible themes of future research the connection between IR, risk management, audit and assurance processes.

Some studies have already considered the state of development of integrated reporting, beginning to define theoretical models for research analysis into IR. Eccles et al. (2015) have found four fundamental phases in integrated reporting development. The first phase, called "company experimentation", involves the early experiences of pioneer companies in IR. This phase began in 2002 and is still ongoing, with experiences that are increasingly consistent and in line with the IIRC framework. The second phase is called "expert commentary" and consists of an attempt to build a theoretical basis for future development of the movement. This began in around 2005 and involves audit firms, academics and various experts. The third phase is "codification", that is, definition of a framework by international standard setters, the IIRC in particular. The fourth and final phase is that of "institutionalization", which endeavors to set integrated reporting in a legal, regulatory context (EU, Directive 95/2014, Disclosure of non-financial and diversity information by certain large undertakings and groups).

Currently, the aspect that has received least attention in the literature is the state of the art of scientific research on IR published so far. It is important to consider future lines of activity, but this should be based on close analysis of research into integrated reporting carried out so far. Our study intends to help fill this gap, through an overall exploratory analysis of IR research, as a basis for contemplating future lines of study.

\section{Method}

Our research is exploratory in nature and investigates the dissemination and dynamics of IR studies from when the concept appeared to date. We have achieved this by using three of the main databases for scientific publications - Science Direct, Ebsco and Scopus - which were consulted up until 28th December 2015. To provide an even more organic "picture" of studies on integrated reporting, research was extended to books not contained in the previously consulted databases, using the Google Scholar research engine. Only publications in the English language in scientific journals and volumes were taken into consideration.

This research approach has already been used by other authors to analyze studies on corporate social responsibility (Danilovic et al., 2015) and to examine the dissemination of specific themes in scientific research, such as the informal sector, sustainable development and social capital, fashion in organization theory and new ideas in research (Bort and Kieser, 2011; Heap and Parikh, 2005; McNeill, 2006).

Our research was carried out in various phases. Firstly, we interrogated Science Direct, Ebsco and Scopus to gather records associated with the search key "integrated reporting". Then, we analysed the records obtained in greater detail, to see whether their contents discussed the subject of our research. We looked at the title, the abstract and the text, thus excluding nonrelevant results.

One potential problem was that the records we identified sometimes appeared 


\section{MIN Macrothink}

International Journal of Accounting and Financial Reporting

ISSN 2162-3082

2017, Vol. 7, No. 1

contemporaneously in all three search engines, increasing the risk of overestimating our results, if not carefully evaluated. We therefore identified studies present in two or more databases, considering their double indexing to determine the total and thereby removing this potential misrepresentation.

The following step was to organize studies from the three databases in order of date, to identify the trend of scientific work. We then went on to analyze the placing of articles in scientific journals. To do this, we identified the number of contributions on integrated reporting published in journals indexed in Science Direct, Ebsco and Scopus.

In addition to this analysis, we evaluated the subject area of interest for each journal. To do this, we used the SCImago Journal and Country Rank database, considering the first subject area of each journal, in order to find the thematic area of journals that published articles on integrated reporting.

Finally, we examined research methods used by authors of the published papers. Methods of enquiry can be divided between empirical qualitative research (analysis of events, case studies, analysis of text and images) and empirical quantitative research (analysis of numbers, statistics, frequencies, distributions) (Flick, 2009). To this can be added the normative research approach, which analyses the expected features of specific phenomena or object (Anessi Pessina et al., 2016). Finally, Shields (1997) suggests classifying research methods into theory, (mathematical) analysis, surveys, case/field research, archival research, simulation and experiments.

The analysis we give here uses a classification of theory, empirical qualitative research and empirical quantitative research.

\section{Results and Discussion}

Research using the keyword "integrated reporting" brought up 485 results for Science Direct, 28 for Ebsco and 174 for Scopus. The title, abstract and text of these records were then analyzed to identify scientific studies that, from various perspectives, dealt with integrated reporting. This gave us a final result of 109 papers and book chapters, divided among 17 records for Science Direct, 10 for Ebsco and 82 for Scopus (Appendix A).

It is interesting to examine the distribution over time of these works, to see whether this new research theme developed in a regular manner from 2011 or whether, vice versa, there has been a real "explosion" in recent years. To evaluate timing, the 109 papers were divided into separate databases (Table 1). 


\section{Macrothink}

International Journal of Accounting and Financial Reporting

ISSN 2162-3082

2017, Vol. 7, No. 1

Table 1: Distribution over time of papers in the three databases (Science Direct, Ebsco, Scopus)

\begin{tabular}{|l|l|l|l|l|l|l|l|l|}
\hline & $\mathbf{2 0 0 9}$ & $\mathbf{2 0 1 0}$ & $\mathbf{2 0 1 1}$ & $\mathbf{2 0 1 2}$ & $\mathbf{2 0 1 3}$ & $\mathbf{2 0 1 4}$ & $\mathbf{2 0 1 5}$ & Total \\
\hline Science Direct & 0 & 0 & 0 & 0 & 5 & 4 & 8 & 17 \\
\hline Ebsco & 1 & 1 & 0 & 0 & 2 & 6 & 0 & 10 \\
\hline Scopus & 0 & 1 & 1 & 3 & 33 & 13 & 31 & 82 \\
\hline Total & $\mathbf{1}$ & $\mathbf{2}$ & $\mathbf{1}$ & $\mathbf{3}$ & $\mathbf{4 0}$ & $\mathbf{2 3}$ & $\mathbf{3 9}$ & $\mathbf{1 0 9}$ \\
\hline
\end{tabular}

This trend, slackening in 2014, was maintained in 2015, when there were 39 papers on integrated reporting. It may therefore be assumed that the trend will continue over the next few years, with much attention being devoted by academics to the question of integrated reporting.

These first results had to be carefully evaluated, to prevent research being "contaminated" by records found contemporaneously in Science Direct, Ebsco and Scopus. This would have led to over-estimation of scientific studies, where the same record appeared in two or more databases.

Examination of records present in both Science Direct and Scopus revealed 5 studies found on both databases. These records were considered only once in the quantitative survey and counted against Science Direct, the first database in order of interrogation. In other words, the double records were counted against Science Direct, which was the first database to be analysed.

The same approach was taken with Ebsco and Scopus, revealing 2 records found twice, which were counted against Ebsco.

Consequently, the number of papers on integrated reporting in the three databases is 102 , after removing the double entries.

The trend over time of papers found in Science Direct, Ebsco and Scopus is given in Figure 1 showing, once again, an explosion of the theme in 2013 and a sustained rhythm, slackening in 2014, of scientific studies over the last three years. These results match the analysis that includes those studies appearing twice. 


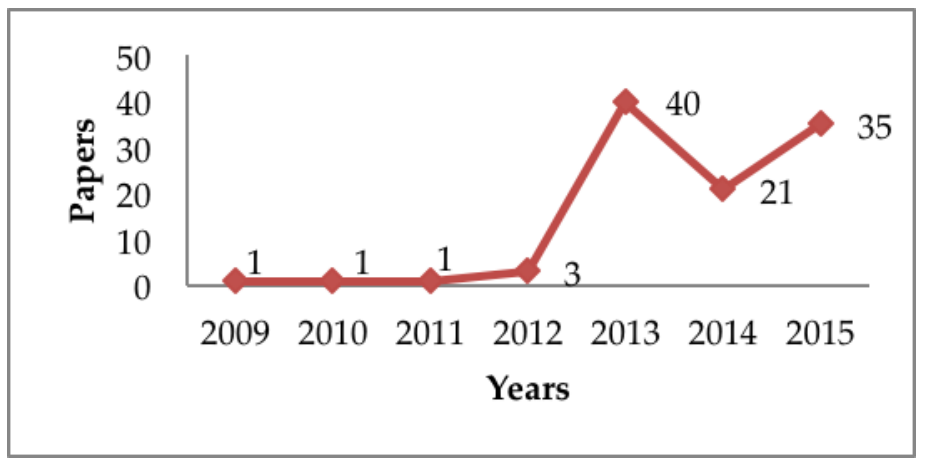

Figure 1: Distribution over time of papers in the three databases (Science Direct, Ebsco, Scopus), after removing double entries

To evaluate the complete panorama of scientific work on the subject, we extended our research to scientific books, consulting the Google Scholar database, using the keyword "integrated reporting". The title, abstract and text of the records obtained were again analyzed, resulting in 7 books on our subject of research.

To evaluate the complete panorama of scientific work on the subject, we extended our research to scientific books, consulting the Google Scholar database, using the keyword "integrated reporting". The title, abstract and text of the records obtained were again analyzed, resulting in 7 books on our subject of research.

In short, it may be said that the scientific community has produced 102 papers and 7 books on the theme of integrated reporting, for a total of 109 works. This result, thus calculated, again confirms the recent emersion of the theme which, as indicated in the framework of Eccles et al. (2015), in 2011 is in the "institutionalization" phase. This phase, once the standards for integrated reporting had been defined (IIRC, 2013a, 2013b and 2013c; Institute of Directors Southern Africa, 2009), saw a gradual increase in studies. One might expect a gradual growth of scientific debate over the next few years. The results confirm fast, constant growth in the number of studies, with over one hundred works produced in less than four years.

Analysis of distribution over time of papers and books also confirms results already found (Fig. 2). In this case, the 2012-over-2013 increase is even more marked - from 3 to 44 products - while there is continuous production, albeit less intense, in the two years that follow. 


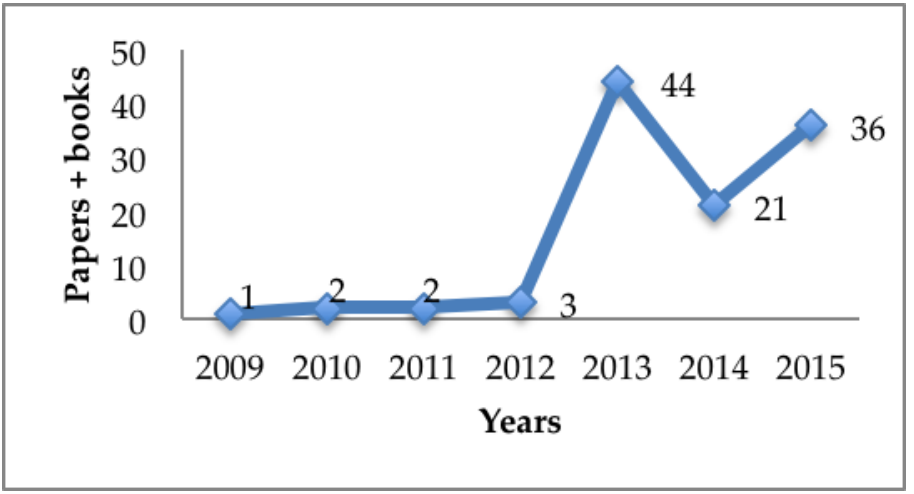

Figure 2: Distribution over time of papers in the three databases (Science Direct, Ebsco, Scopus), after removing double entries

These results were then further examined to consider the type of scientific work: journal papers, book chapters or books. Journal papers clearly predominated. The 17 works selected by Science Direct were all journal papers, Ebsco had 8 journal papers and 2 book chapters and Scopus had 25 book chapters and 57 journal papers. If we add the 7 books from Google Scholar, records for books were 34 , equal to $31 \%$ of the overall total of scientific works.

The papers were then analysed in relation to the journal where they were published - results shown in Table 2. As above, papers featuring in more than one database, shown between rounded brackets in the table, were only counted once in the "Total" column.

Table 2: Placing of journal papers

\begin{tabular}{|l|l|l|l|l|}
\hline Journal & $\begin{array}{l}\text { Science } \\
\text { Direct }\end{array}$ & Ebsco & Scopus & Total \\
\hline $\begin{array}{l}\text { Accounting and Business Research } \\
\text { (ISSN:00014788) }\end{array}$ & & & 1 & 1 \\
\hline Accounting Education (ISSN: 09639284) & & 4 & 4 \\
\hline $\begin{array}{l}\text { Accounting, Auditing and Accountability Journal } \\
\text { (ISSN: 09513574) }\end{array}$ & & 8 & 8 \\
\hline Actual Problems of Economics (ISSN: 19936788) & & $(1)$ & $(1)$ & 1 \\
\hline Advanced Science Letters (ISSN: 19366612) & & 1 & 1 \\
\hline $\begin{array}{l}\text { Agris On-line Papers in Economics and Informatics } \\
\text { (ISSN: 18041930) }\end{array}$ & & & 1 & 1 \\
\hline Amfiteatru Economic (ISSN: 15829146) & & 2 & 2 \\
\hline
\end{tabular}




\begin{tabular}{|c|c|c|c|c|}
\hline $\begin{array}{l}\text { Annales Universitatis Apulensis } \quad \text { Series } \\
\text { Oeconomica (ISSN: 14539306) }\end{array}$ & & 1 & & 1 \\
\hline Asian Social Science (ISSN: 19112017) & & & 1 & 1 \\
\hline Australian Accounting Review (ISSN: 10356908) & & & 1 & 1 \\
\hline Banks and Bank Systems (ISSN: 1816-7403) & & 1 & & 1 \\
\hline Bulletin of Geography (ISSN: 17324254) & & & 1 & 1 \\
\hline $\begin{array}{l}\text { Business Strategy and the Environment (ISSN: } \\
\text { 09644733) }\end{array}$ & & & 1 & 1 \\
\hline $\begin{array}{l}\text { Corporate Ownership and Control (ISSN: } \\
\text { 17279232) }\end{array}$ & & & 1 & 1 \\
\hline $\begin{array}{l}\text { Corporate Social Responsibility and Environmental } \\
\text { Management (ISSN: 15353958) }\end{array}$ & & & 2 & 2 \\
\hline $\begin{array}{l}\text { Critical Perspectives on Accounting (ISSN: } \\
\text { 10452354) }\end{array}$ & (4) & & (4) & 4 \\
\hline $\begin{array}{l}\text { Critical Studies on Corporate Responsibility, } \\
\text { Governance and Sustainability (ISSN: 20439059) }\end{array}$ & & & 1 & 1 \\
\hline Economics Alternatives (ISSN: 13127462) & & 1 & & 1 \\
\hline Entrepreneurial Executive (ISSN: 10878955) & & & 1 & 1 \\
\hline Environmental Economics (ISSN: 19986041) & & 1 & & 1 \\
\hline $\begin{array}{l}\text { Environmental Quality Management (ISSN: } \\
\text { 10881913) }\end{array}$ & & & 1 & 1 \\
\hline International Business Review (ISSN: 09695931) & 1 & & 1 & 2 \\
\hline $\begin{array}{l}\text { International Journal of Digital Accounting } \\
\text { Research (ISSN: } 15778517 \text { ) }\end{array}$ & & & 1 & 1 \\
\hline Issues in Accounting Education (ISSN: 15587983) & & & 1 & 1 \\
\hline
\end{tabular}




\begin{tabular}{|c|c|c|c|c|}
\hline $\begin{array}{l}\text { Journal of Academy of Business and Economics } \\
\text { (ISSN: 1542-8710) }\end{array}$ & & 1 & & 1 \\
\hline Journal of Business Ethics (ISSN: 01674544) & & & 4 & 4 \\
\hline Journal of Cleaner Production (ISSN: 09596526) & 3 & & 1 & 4 \\
\hline Journal of Intellectual Capital (ISSN: 14691930) & & & 3 & 3 \\
\hline $\begin{array}{l}\text { Journal of International Academy for Case Studies } \\
\text { (ISSN: 10784950) }\end{array}$ & & & 1 & 1 \\
\hline $\begin{array}{l}\text { Journal of International Business and Economics } \\
\text { (ISSN: 15448037) }\end{array}$ & & & 1 & 1 \\
\hline $\begin{array}{l}\text { Journal of International Financial Management and } \\
\text { Accounting (ISSN: 09541314) }\end{array}$ & & & 1 & 1 \\
\hline $\begin{array}{l}\text { Journal of Legal, Ethical and Regulatory Issues } \\
\text { (ISSN: 15440036) }\end{array}$ & & & 1 & 1 \\
\hline $\begin{array}{l}\text { Journal of Management and Governance (ISSN: } \\
\text { 13853457) }\end{array}$ & & & 1 & 1 \\
\hline Journal of Management Control (ISSN: 21914761) & & & 1 & 1 \\
\hline Managerial Economics (ISSN: 18981143) & & 1 & & 1 \\
\hline $\begin{array}{l}\text { Procedia Economics and Finance (ISSN: } \\
\text { 22125671) }\end{array}$ & 3 & & & 3 \\
\hline $\begin{array}{l}\text { Procedia Social and Behavioural Sciences (ISSN: } \\
\text { 18770428) }\end{array}$ & 3 & & & 3 \\
\hline $\begin{array}{l}\text { Proceedings of the Institutions of Civil engineers: } \\
\text { engineering sustainability (ISSN: 14784629) }\end{array}$ & & & 1 & 1 \\
\hline Public Relations Review (ISSN: 03638111) & (2) & & (1) & 2 \\
\hline Review of Business Research (ISSN: 15462609) & & 1 & & 1 \\
\hline Review of Quantitative Finance and Accounting & & & 1 & 1 \\
\hline
\end{tabular}




\begin{tabular}{|c|c|c|c|c|}
\hline (ISSN: 0924865X) & & & & \\
\hline $\begin{array}{l}\text { Social and Environmental Accountability Journal } \\
\text { (ISSN: 0969160X) }\end{array}$ & & & 1 & 1 \\
\hline $\begin{array}{l}\text { Sustainability Accounting, Management and Policy } \\
\text { Journal (ISSN: 20408021) }\end{array}$ & & & 5 & 5 \\
\hline The British Accouning Review (ISSN: 08908389) & 1 & & & 1 \\
\hline Total & 17 & 8 & 58 & 77 \\
\hline
\end{tabular}

Numerous journals (44) have published contributions on integrated reporting. The six journals that published most on the subject contained between 4 and 8 papers, while the others contained more limited numbers. The most "active" journals were: Accounting, Auditing and Accountability Journal, Sustainability Accounting and Policy Journal, Accounting Education, Critical Perspectives on Accounting, Journal of Business Ethics and Journal of Cleaner Production. It is worth noting that two of the more active journals (Accounting, Auditing and Accountability Journal and Accounting Education) published the majority of contributions on the subject in two special editions, in 2014 and 2013 respectively.

The analysis then proceeded to consider the area of interest of the journals publishing papers on integrated reporting (Fig. 3). There was a clear predominance of journals in the area of "Business Management and Accounting" (57\%), followed by those dealing with "Economics, Econometrics and Finance" (20\%). After these, the papers were found in journals with a broader range of interest, such as "Arts and Humanities" (7\%) and "Social Sciences" (5\%).

Of significance, finally, were journals that had published just one article on integrated reporting, whose areas were quite varied, such as "Computer Science", "Agricultural and Biological Sciences", "Environmental Science", "Psychology" and "Engineering". 


\section{Macrothink}

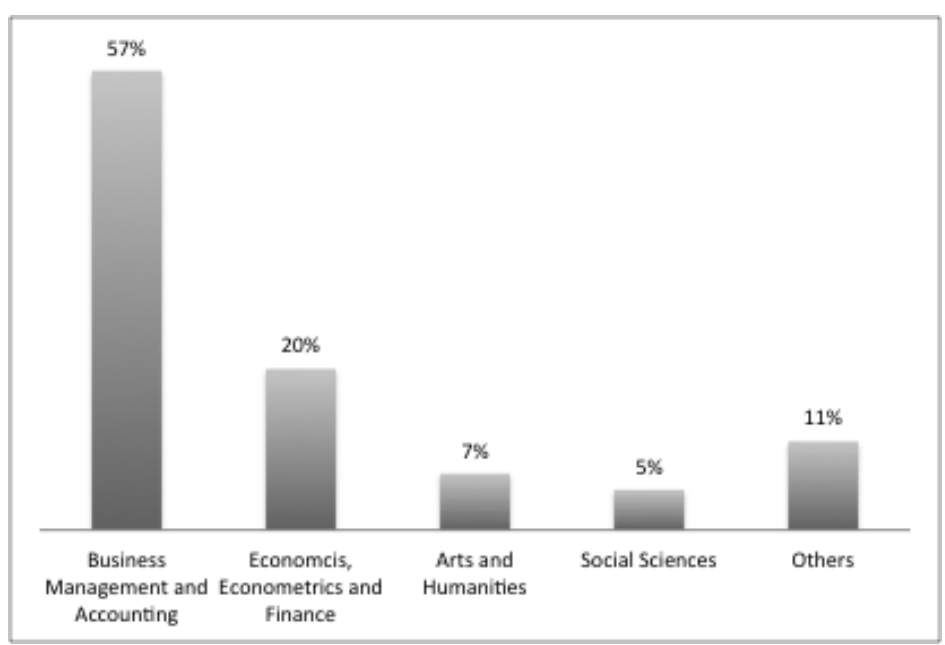

Figure 3: Subject area of journals

Lastly, we examined the research method used in the journal papers. Our results are shown in this table, where approaches are divided between theoretical, empirical qualitative and empirical quantitative research (Table 3).

Table 3: Research method used by journal papers

\begin{tabular}{|l|l|l|l|}
\hline Year & Theory & Qualitative & Quantitative \\
\hline 2015 & 12 & 20 & 9 \\
\hline 2014 & 10 & 11 & 0 \\
\hline 2013 & 10 & 4 & 5 \\
\hline 2012 & 2 & 0 & 1 \\
\hline 2011 & 1 & 0 & 0 \\
\hline Total & $\mathbf{3 5}$ & $\mathbf{3 5}$ & $\mathbf{1 5}$ \\
\hline
\end{tabular}

To begin with, the results showed that journal papers were concentrated in the last five years analyzed, with none found in 2009 and 2010. Consequently, we observe that early studies on integrated reporting were mainly published in books. Only later were studies published in the journals found on the databases.

The majority of the articles used a qualitative research approach or invited theoretical discussion. Only a small proportion used quantitative approaches. Theory papers were evenly distributed over the last three years, testifying to the necessity of finding an ever-stronger theoretical framework for the question of integrated reporting. The past two years have seen a growth in quantitative and, above all, qualitative research on the subject. The latter has been 
particularly used by studies published in 2015 .

For qualitative research, the line of activity currently most popular with scholars, we made a more detailed analysis of the types of method used. Qualitative research methods were divided into archival, case study, field research, interview, survey and content analysis (Table 4).

The most common qualitative research method was content analysis, followed by case study and field research. Content analysis, in 2015, was the most popular method and was growing strongly with respect to preceding years. Less frequent use was made of interviews and surveys, while archival research was found only sporadically and in the last year.

Table 4: Qualitative research methods used in journal papers

\begin{tabular}{|c|c|c|c|c|c|c|}
\hline Year & Archival & Case study & Field research & Interviews & Survey & Content analysis \\
\hline 2015 & 1 & 4 & 4 & 2 & 2 & 7 \\
\hline 2014 & & 2 & 3 & 2 & 2 & 2 \\
\hline 2013 & & 1 & & & & 3 \\
\hline 2012 & & & & & & \\
\hline 2011 & & & & & & \\
\hline Total & 1 & 7 & 7 & 4 & 4 & 12 \\
\hline
\end{tabular}

It should be noted that these research methods were not exclusive. In some cases (9), scholars' research strategies combined various approaches. Such studies were concentrated almost exclusively in 2015 (7 cases), once again confirming the increasing "maturity" of integrated reporting research. Four studies, in particular, used partly qualitative and partly quantitative research methods - an interesting prospect for research in the future.

\section{Conclusion}

Integrated reporting has recently become a model for combining in "One Report" the various aspects of non-financial information. The first experiences came from pioneer companies who had tried this new model of reporting. More recently, the theme has become subject of scientific investigation and research. However, there is still need to stimulate academic debate, defining solid theoretical frameworks to act as bases for future experiences of IR, and to explore current knowledge using a variety of research methods.

Our research has shown how, since 2013, there has been an authentic "explosion" in integrated reporting, with exponential growth in scientific studies. This trend has remained constant over the past three years, albeit slackening slightly in 2014. Since 2011, no fewer 
than 109 papers and books on the subject were published, with a real escalation in 2013-over2012 results.

Growing focus of attention on IR ran parallel to the long process of defining a framework for it, mainly involving the IIRC and South African experiences. Currently, according to the model of Eccles et al. [31], the evolution of IR is passing from the "codification" to the "institutionalization" stage. This latter will see increasing intervention from national and international bodies and standard setters. This is the very moment for scientific research to make a considerable contribution towards defining the concept of IR and towards its subsequent "institutionalization". In the next few years, therefore, we may expect a strong debate on integrated reporting, as already evident starting from 2013.

Database analysis (Science Direct, Ebsco and Scopus) has also shown that early studies on the subject were mainly found in books and only later were papers published by international journals. In recent years, as debate grows, journal papers clearly prevail over books, which currently represent only $31 \%$ of research. Furthermore, the journals publishing IR studies have so far been numerous (44), mostly (57\%) from the area of "Business Management and Accounting", as might be expected, given that IR deals with non-financial accounting.

We then considered the research methods used in the journal papers, finding a predominance of theoretical and qualitative approaches. The former approach highlights the need, in this transition between "codification" and "institutionalization", of a stronger, improved theoretical framework for a theme that, in effect, offers interesting opportunities for future research.

In the past two years, considerable attention has been given to qualitative studies, with frequent use of content analysis (the most common method in 2015), case studies and field research. Recent prevalence of content analysis shows a need for analyzing the methods used by companies in applying IR principles and the necessity of better understanding the structure of IR. Content analysis is, indeed, a research method with interesting prospects for future studies on integrated reporting.

Case studies, also frequently used, show a need to understand the changes brought about by applying IR to corporate strategy, management and value creation [41-42]. These aspects currently require more detailed investigation. Recent papers, too, have designed their research using mixed methods in order to gain greater understanding of the determining factors of this yet-unexplored phenomenon [43-44].

Quantitative research methods, also on the increase in 2015, offer an interesting opportunity for future research. They may, for example, throw light on the relationship between value creation referring to the six capitals of IR and other variables, such as corporate financial performance and value [45].

Our research has certain limits that might also represent future developments. Firstly, research might be extended to other databases beyond Science Direct, Ebsco and Scopus, which would broaden the range of investigation and enable further verification of the recent growth in IR research. 


\section{Macrothink}

International Journal of Accounting and Financial Reporting

ISSN 2162-3082 2017, Vol. 7, No. 1

Secondly, the timeframe of our research is still limited. It might be interesting to repeat the analysis in future, to verify whether the developments envisaged above effectively took place.

Finally, research might be broadened to include other kinds of scientific studies, such as conference proceedings, industrial reports and papers in languages other than English.

\section{References}

Adams, S. \& Simnett, R. (2011). Integrated reporting: an opportunity for Australia not-forprofit sector. Australian Accounting Review. 21(3). 292-301.

Anessi Pessina, E., Barbera, C., Sicilia, M. \& Steccolini, I. (2016). Public sector budgeting: an European review of accounting and public-management journals. Accounting, Auditing \& Accountability Journal. 29(3). 491-519.

Beck, C., Dumay, J. \& Frost, G. (2015). In pursuit of a 'single source of truth': from threatened legitimacy to integrated reporting. Journal of Business Ethics. first online. 1-15.

Bort, S. \& Kieser, A. (2011). Fashion in organization theory: an empirical analysis of the diffusion of theoretical concepts. Organization Studies. 32(5). 55-681.

Bouten, L.A. \& Hoozée, S.B. (2015). Challenges in sustainability and integrated reporting. Issues in Accounting Education. 30(4). 373-381.

Cheng, M., Green, W., Coradie, P., Konishi, N. \& Romi A. (2014). The International Integrated Reporting Framework: key issues and future research opportunities. Journal of International Financial Management \& Accounting 25(1). 90-119.

Cohen, J., Holder-Webb, L.L., Nath, L. \& Wood, D. (2012). Corporate reporting on nonfinancial leading indicators of economic performance and sustainability. Accounting Horizons. 26(1). 65-90.

Danilovic, M., Hensbergen, M., Hoveskog, M. \& Zadayannaya, L. (2015). Exploring diffusion and dynamics of corporate social responsibility. Corporate Social Responsibility and Environmental Management. 22(3). 129-141.

de Villiers, C., Rinaldi, L. \& Unerman, J. (2014). Integrated reporting: insights, gaps and an agenda for future research. Accounting, Auditing \& Accountability Journal. 27(7). 10421067.

Dey, C. \& Burns, J. (2010). Integrated reporting at Novo Nordisk. In A. Hopwood, J. Unerman, \& J. Fries (Eds.), Accounting for Sustainability: Practical Insights (pp. 197-214). London: Earthscan.

Eccles, R.G., Cheng, B. \& Saltzman, D. (Eds.) (2010). The landscape of integrated reporting reflections and next steps. Cambridge: Harvard Business School.

Eccles, R.G. \& Krzus, M.P. (2010). One report: integrated reporting for a sustainable strategy. Hoboken: Wiley. 


\section{$\Lambda$ Macrothink}

International Journal of Accounting and Financial Reporting ISSN 2162-3082 2017, Vol. 7, No. 1

Eccles, R.G. \& Armbrester, K. (2011). Two disruptive ideas combined. Integrated reporting in the cloud. IESE Insight. 8. 13-20.

Eccles, R.G., Krzus, M.P. \& Ribot, S. (2015). Meaning and momentum in the integrated reporting movement. Journal of Applied Corporate Finance. 27(2). 8-17.

Flick, U. (2009). An introduction to qualitative research (4th ed.). Thousand Oaks: Sage Publications.

Frìas-Aceituno, J.V., Rodrìguez-Ariza, L. \& Garcìas-Sànchez, J.M. (2013a). Is integrated reporting determined by a country's legal system? An exploratory study. Journal of Cleaner Production. 44. 45-55.

Frias-Aceituno, J.V., Rodriguez-Ariza, L. \& Garcia-Sanchez, I.M. (2013b). The role of the board in the dissemination of integrated corporate social reporting. Corporate Social Responsibility and Environmental Management. 20(4). 219-233.

Garcìa-Sanchez, I., Rodrìguez-Ariza, L. \& Frìas-Aceituno, J. (2013). The cultural system and integrated reporting. International Business Review. 22(5). 828-838.

Haller, A. and van Staden, C. (2014). The value added statement - an appropriate instrument for integrated reporting. Accounting, Auditing \& Accountability Journal. 27(7). 1190-1216.

Heap, S.P.H. \& Parikh, A. (2005). The diffusion of ideas in the academy: a quantitative illustration from economics. Research Policy. 34(10). 1619-1632.

Higgins, C., Stubbs, W. \& Tyron, L. (2014). Walking the talk(s): organisational narratives of integrated reporting. Accounting, Auditing \& Accountability Journal. 27(7). 1090-1119.

Hong, A. (2010). Southwest Airlines One Report review. In R.G. Eccles, B. Cheng, \& D. Saltzman (Eds.). The landscape of integrated reporting reflections and next steps (pp. 94-99). Cambridge: Harvard Business School.

IIRC (2011). Towards integrated reporting, communicating value in the 21st Century. [Online]. Available: http://integratedreporting.org/wp-content/uploads/2011/09/IRDiscussion-Paper-2011_spreads.pdf (November 10, 2016).

IIRC (2013a). The international <IR> Framework, International Integrated Reporting Council. [Online]. Available: http://integratedreporting.org/wp-content/uploads/2015/03/1312-08-THE-INTERNATIONAL-IR-FRAMEWORK-2-1.pdf (November 10, 2016).

IIRC (2013b). Basis for conclusions. International <IR > Framework, International Integrated Reporting Council. [Online] Available: http://integratedreporting.org/wpcontent/uploads/2013/12/13-12-08-Basis-for-conclusions-IR.pdf (November 10, 2016).

IIRC (2013c). Consultation draft of the International <IR> Framework, International Integrated Reporting Council. [Online] Available: http://integratedreporting.org/wpcontent/uploads/2013/03/Consultation-Draft-of-the-InternationalIRFramework.pdf (November 10, 2016). 


\section{MInstitute Macrothink $_{\text {Int }}^{\text {Intis }}$}

International Journal of Accounting and Financial Reporting

ISSN 2162-3082 2017, Vol. 7, No. 1

IIRC/EY (2013). Background Paper for <IR>, Value Creation. [Online] Available: http://integratedreporting.org/wp-content/uploads/2013/08/Background-Paper-ValueCreation.pdf (November 10, 2016).

Jensen, J.C. \& Berg, N. (2012), "Determinants of traditional sustainability reporting versus integrated reporting. An institutionalist approach. Business Strategy and the Environment. 21(5). 299-316.

Kanzer, A.M. (2010). Toward a model for sustainable capital allocation. The landscape of integrated reporting. [Online] Available: http://hbswk.hbs.edu/item/6532.html (accessed 13 January 2016).

Kolk, A. (2004). A decade of sustainability reporting: developments and significance. International Journal of Environmental and Sustainable Development. 3(1). 51-64.

Kolk, A. (2010). Trajectories of sustainability reporting by MNCs. Journal of World Business. 45(4). 367-374.

Lee, K.W. \& Yeo, G.H.H. (2015). The association between integrated reporting and firm valuation. Review of Quantitative Finance and Accounting. First online. 1-30.

Lodhia, S. (2015). Exploring the transition to integrated reporting through a practice lens: an Australian customer owned bank perspective. Journal of Business Ethics. 129(3). 585-598.

Institute of Directors Southern Africa (2009). King report on governance for South Africa 2009. [Online] Available: https://jutalaw.co.za/uploads/King_III_Report/\#p=1 (November 15, 2016).

Melloni, G., Stacchezzini, R. \& Lai, A. (2016). The tone of business model disclosure: an impression management analysis of the integrated reports. Journal of Management and Governance. 20(2). 295-320.

McNeill, D. (2006). The diffusion of ideas in development theory and policy. Global Social Policy. 6(3). 334-354.

Owen, D. (2006). Emerging issues in sustainability reporting. Business Strategy and the Environment. 15(4). 217-218.

Rensburg, R. \& Botha, E. (2014). Is integrated reporting the silver bullet of financial communication? A stakeholder perspective from South Africa. Public Relations Review. 40(2). 144-152.

Robertson, F.A. \& Samy, M. (2015). Factors affecting the diffusion of integrated reporting - a UK FTSE 100 perspective. Sustainability Accounting, Management and Policy Journal. 6(2). 190-223.

Rossouw, R. (2010). King III integrated report. Why it's crucial to plan ahead. Keeping Good Companies. 62. 537-538.

Shields, M.D. (1997). Research in management accounting by North Americans in the 1990s. 


\section{Macrothink \\ International Journal of Accounting and Financial Reporting \\ ISSN 2162-3082 2017, Vol. 7, No. 1}

Journal of Management Accounting Research. (9). 3-61.

Sierra-Garcìa, L., Zorio-Grima, A. \& Garcìa-Benau, M. (2015). Stakeholder engagement, corporate social responsibility and integrated reporting: an exploratory study. Corporate Social Responsibility and Environmental Management. 22(5). 286-304.

Stubbs, W. \& Higgins, C. (2014). Integrated reporting and internal mechanisms of change. Accounting, Auditing \& Accountability Journal. 27(7). 1068-1089.

Veltri, S. \& Silvestri, A. (2015). The Free State University integrated reporting: a critical consideration. Journal of Intellectual Capital. 16(2). 443-462.

White, A.L. (2010). The five capitals of integrated reporting: toward a holistic architecture for corporate disclosure. The landscape of integrated reporting. [Online] Available: http://hbswk.hbs.edu/item/6532.html (December 21, 2016).

\section{Appendix}

Appendix 1: The results of databases

Database: ScienceDirect

1) Adams, C.A. (2015), "The International Integrated Reporting Council: a call to action", Critical Perspectives on Accounting, Vol. 27, pp. 23-28.

2) Beattie, V. and Smith, S.J. (2013), "Value creation and business models: refocusing the intellectual capital debate", The British Accounting Review, Vol. 45 No. 4, pp. 243-254.

3) Dragu, I.M. and Tiron-Tudor, A. (2013), "The Integrated Reporting Initiative from an institutional perspective: emergent factors", Procedia - Social and Behavioral Sciences, Vol. 92, pp. 275-279

4) Dragu, I.M. and Tiron-Tudor, A. (2014), "Research agenda on integrated reporting: new emergent theory and practice", Procedia Economics and Finance, Vol. 15, pp. 221-227.

5) Flower, J. (2015), “The International Integrated Reporting Council: a story of failure", Critical Perspectives on Accounting, Vol. 27, pp. 1-17.

6) Frías-Aceituno, J.V., Rodríguez-Arizam, L. and García-Sánchez, I.M. (2013), "Is integrated reporting determined by a country's legal system? An exploratory study", Journal of Cleaner Production, Vol. 44, pp. 45-55.

7) García-Sánchez, I.M., Rodríguez-Ariza, L. and Frías-Aceituno, J.V. (2013), “The cultural system and integrated reporting”, International Business Review, Vol. 22 No. 5, pp. 828-838.

8) Kaspina, R. (2015), “Continuing professional development of accounting and auditing: Russian experience and challenges", Procedia - Social and Behavioral Sciences, Vol. 191, pp. 550-553.

9) Hahn, R. and Kühnen, M. (2013), "Determinants of sustainability reporting: a review of results, trends, theory, and opportunities in an expanding field of research", Journal of 


\section{1ll Macrothink}

International Journal of Accounting and Financial Reporting

ISSN 2162-3082

2017, Vol. 7, No. 1

Cleaner Production, Vol. 59, pp. 5-21.

10) Havlová, K. (2015), "What integrated reporting changed: the case study of early adopters", Procedia Economics and Finance, Vol. 34, pp. 231-237.

11) Lodhia, S., and Hess N. (2014), "Sustainability accounting and reporting in the mining industry: current literature and directions for future research", Journal of Cleaner Production, Vol. 84, pp. 43-50.

12) Meintjes, C. and Grobler, A.F. (2014), "Do public relations professionals understand corporate governance issues well enough to advise companies on stakeholder relationship management?", Public Relations Review, Vol. 40 No. 2, pp. 161-170.

13) Oprisor, T. (2015), “Auditing integrated reports: are there solutions to this puzzle?", Procedia Economics and Finance, Vol. 25, pp. 87-95.

14) Rambaud, A. and Richard, J. (2015), "The "triple depreciation line" instead of the "triple bottom line": towards a genuine integrated reporting", Critical Perspectives on Accounting, Vol. 33, pp. 92-116.

15) Rensburg, R. and Botha, E. (2014), "Is integrated reporting the silver bullet of financial communication? A stakeholder perspective from South Africa", Public Relations Review, Vol. 40, No. 2, pp. 144-152.

16) Sudana, I.P. (2015), "Sustainable development and reconceptualization of financial statements”, Procedia - Social and Behavioral Sciences, Vol. 211, pp. 157-162.

17) Thomson, I. (2015), “'But does sustainability need capitalism or an integrated report' a commentary on 'The International Integrated Reporting Council: A story of failure' by Flower J.”, Critical Perspectives on Accounting, Vol. 27, pp. 18-22.

Database: Ebsco

1) Bernardi, C., Demartini, P. and Paoloni, M. (2014), "Do socially responsible investors value integrated reporting?", Journal of Academy of Business and Economics, Vol. 14, pp. $135-145$.

2) Buys, P.W. and van Niekerk, E. (2014), "The South African financial services industry's integrated reporting compliance with the global reporting initiative framework", Banks and Bank Systems, Vol. 9 No. 4, pp. 107-115.

3) Dey, C. and Burns, J. (2010), "Integrated reporting at Novo Nordisk", in Hopwood, A., Unerman, J. and Fires, J. (eds), Accounting for Sustainability: Practical Insights, Routledge, London, pp. 215-232.

4) Dumitru, M., Glavan, M.E., Gorgan, C. and Dumitru, V.F. (2013), "International integrated reporting framework: a case study in the software industry", Annales Universitatis Apulensis Series Oeconomica, Vol. 15 No. 1, pp. 24-39. 


\section{I Macrothink}

International Journal of Accounting and Financial Reporting

ISSN 2162-3082

2017, Vol. 7, No. 1

5) Melis, A., Carta, S. and Del Rio, S. (2009), "CSR and integrated triple bottom line reporting in Italy: case study evidence", in Mallin, C.A. (ed), Corporate Social Responsibility: A Case Study Approach, Edward Elgar, Cheltenham, pp. 9-39.

6) Nortje, C., Middelberg, S.L., Oberholzer, M. and Buys, P.W. (2014), "Developing a sustainable balanced scorecard for the oil and gas sector", Environmental Economics, Vol. 5, pp. 52-60.

7) Kuzina, R.W. (2014), "Integrated reporting as a mechanism of increasing business value”, Actual Problems of Economics, Vol. 158, pp. 385-392.

8) Knoll, J. and Feigenbutz, A. (2014), "Integrated reporting - 'One-Size-Fits-All' Solution!?”, Managerial Economics, Vol. 15 No. 2, pp. 165-175.

9) Paoloni, M. and Bernardi, C. (2014), "Bridging the gap between intellectual capital and sustainability reporting current trends and emerging issues", Review of Business Research, Vol. 14, pp. 123-136.

10) Yonkova, B. (2013), "Integrated reporting and SMEs", Economic Alternatives, Vol. 1, pp. 115-125.

\section{Database: Scopus}

1) Abeysekera, I. (2013), "A template for integrated reporting", Journal of Intellectual Capital, Vol. 14 No. 2, pp. 227-245.

2) Adams, S. and Simnett, R. (2011), "Integrated reporting: an opportunity for Australia's not-for-profit sector", Australian Accounting Review, Vol. 21 No. 3, pp. 292-301.

3) Adams, C.A. (2015), “The International Integrated Reporting Council: a call to action", Critical Perspectives on Accounting, Vol. 27, pp. 23-28.

4) Balashova, N.N., Šilerová, E. and Melikhov, V.A. (2015), "Developing the methodology to form integrated reporting of Agroholdings in the Russian Federation", Agris On-line Papers in Economics and Informatics, Vol. 7, pp. 19-29.

5) Barnabè, F. and Giorgino, M.C. (2013), "Integrating business model and strategy", in Busco, C., Frigo, M.L., Riccaboni, A. and Quattrone, P. (eds), Integrated Reporting: Concepts and Cases that Redefine Corporate Accountability, Springer, London, pp. 111-126.

6) Bartocci, L. and Picciaia, F. (2013), "Towards integrated reporting in the public sector", in Busco, C., Frigo, M.L., Riccaboni, A. and Quattrone, P. (eds), Integrated Reporting: Concepts and Cases that Redefine Corporate Accountability, Springer, London, pp. 191-204.

7) Bartocci, L. and Picciaia, F. (2013), "The case of the Auditor-General of South Africa", in Busco, C., Frigo, M.L., Riccaboni, A. and Quattrone, P. (eds), Integrated Reporting: Concepts and Cases that Redefine Corporate Accountability, Springer, London, pp. 331-346.

8) Bartolini, M., Santini, F. and Silvi, R. (2013), "Performance measurement and capitals", 
in Busco, C., Frigo, M.L., Riccaboni, A. and Quattrone, P. (eds), Integrated Reporting: Concepts and Cases that Redefine Corporate Accountability, Springer, London, pp. 127-145.

9) Beck, C., Dumay, J., and Frost, G. (2015), “In pursuit of a 'single source of truth': from threatened legitimacy to integrated reporting”, Journal of Business Ethics, first online, pp. 115.

10) Bouten, L.A. and Hoozée, S.B.C. (2015), "Challenges in sustainability and integrated reporting", Issues in Accounting Education, Vol. 30 No. 4, pp. 373-381.

11) Brown, J. and Dillard, J. (2014), "Integrated reporting: on the need for broadening out and opening up", Accounting, Auditing and Accountability Journal, Vol. 27 No. 7, pp. 11201156.

12) Burritt, R.L. (2012), "Environmental performance accountability: planet, people, profits", Accounting, Auditing and Accountability Journal, Vol. 25, No. 2, pp. 370-405.

13) Busco, C., Frigo. M.L., Quattrone, P. and Riccaboni, A. (2013), "Towards integrated reporting: concepts, elements and principles", in Busco, C., Frigo, M.L., Riccaboni, A. and Quattrone, P. (eds), Integrated Reporting: Concepts and Cases that Redefine Corporate Accountability, Springer, London, pp. 3-18.

14) Busco, C., Maraghini, M.P. and Tommasiello, S. (2013), "The case of Monnalisa", in Busco, C., Frigo, M.L., Riccaboni, A. and Quattrone, P. (eds), Integrated Reporting: Concepts and Cases that Redefine Corporate Accountability, Springer, London, pp. 275-296.

15) Calu, A., Negrei, C., Calu, D.A. and Avram, V. (2015), "Reporting of non-financial performance indicators - A useful tool for a sustainable marketing strategy", Amfiteatru Economic, Vol. 17, pp. 977-993.

16) Carels, C., Maroun, W. and Padia, N. (2013), "Integrated reporting in the South African mining sector", Corporate Ownership and Control, Vol. 11 No. 1, pp. 975-989.

17) Cavazzoni, C. and Orlandi, F. (2013), "The relationship between multinational enterprises and territory in the integrated reporting”, in Busco, C., Frigo, M.L., Riccaboni, A. and Quattrone, P. (eds), Integrated Reporting: Concepts and Cases that Redefine Corporate Accountability, Springer, London, pp. 171-190.

18) Cheng, M., Green, W., Conradie, P., Konishi, N. and Romi, A. (2014), “The international integrated reporting framework: key issues and future research opportunities", Journal of International Financial Management and Accounting, Vol. 25 No. 1, pp. 90-119.

19) Clayton, A.F., Rogerson, J.M. and Rampedi, I. (2015), "Integrated reporting vs. sustainability reporting for corporate responsibility in South Africa", Bulletin of Geography, Vol. 29, pp. 7-17.

20) Correa Ruiz, C. (2013), "A commentary on 'integrated reporting: a review of developments and their implications for the accounting curriculum'", Accounting Education, Vol. 22 No. 4, pp. 360-362. 


\section{Ml Macrothink}

International Journal of Accounting and Financial Reporting

ISSN 2162-3082

2017, Vol. 7, No. 1

21) Coulson, A.B., Adams, C.A., Nugent, M.N. and Haynes, K. (2015), "Exploring metaphors of capitals and the framing of multiple capitals: Challenges and opportunities for $<$ ir>”, Sustainability Accounting, Management and Policy Journal, Vol. 6 No. 3, pp. 290-314.

22) da Cunha Pinto, T., Bandeira, A.M. (2013), "Sustainability reporting and financial reporting: the relevance of an integrated reporting approach", in Muga, H.E. and Thomas, K.D. (eds), Cases on the Diffusion and Adoption of Sustainable Development Practices, Information Science Reference, Hershey, pp. 167-194.

23) Demartini P., Paoloni, M. and Paoloni, P. (2015), "Sustainability and intangibles: evidence of integrated thinking", Journal of International Business and Economics, Vol. 15 No. 2, pp. 107-122.

24) de Villiers, C., Rinaldi, L. and Unerman, J. (2014), "Integrated reporting: Insights, gaps and an agenda for future research", Accounting, Auditing and Accountability Journal, Vol. 27 No. 7, pp. 1042-1067.

25) Dey, C. and Burns, J. (2010), "Integrated Reporting at Novo Nordisk", in Hopwood, A., Unerman, J. and Fires, J. (eds), Accounting for Sustainability: Practical Insights, Routledge, London, pp. 215-232.

26) Donato, D., Bordogna, R. and Busco, C. (2013), "The case of Eni”, in Busco, C., Frigo, M.L., Riccaboni, A. and Quattrone, P. (eds), Integrated Reporting: Concepts and Cases that Redefine Corporate Accountability, Springer, London, pp. 207-223.

27) Dumitru, M., Guşe, R.G., Feleagă, L., Mangiuc, D.M. and Feldioreanu, A.I. (2015), "Marketing communications of value creation in sustainable organizations. The practice of integrated reports", Amfiteatru Economic, Vol. 17, pp. 955-976.

28) Fasan, M. (2013), "Annual reports, sustainability reports and integrated reports: trends in corporate disclosure", in Busco, C., Frigo, M.L., Riccaboni, A. and Quattrone, P. (eds), Integrated Reporting: Concepts and Cases that Redefine Corporate Accountability, Springer, London, pp. 41-57.

29) Flower, J. (2015), “The International Integrated Reporting Council: a story of failure", Critical Perspectives on Accounting, Vol. 27, pp. 1-17.

30) Frias-Aceituno, J.V., Rodriguez-Ariza, L. and Garcia-Sanchez, I.M. (2013), "The role of the board in the dissemination of integrated corporate social reporting", Corporate Social Responsibility and Environmental Management, Vol. 20 No. 4, pp. 219-233.

31) Frías-Aceituno, J.V., Rodríguez-Ariza, L. and García-Sánchez, I.M. (2013), "Is integrated reporting determined by a country's legal system? An exploratory study”, Journal of Cleaner Production, Vol. 44, pp. 45-55.

32) García-Sánchez, I.M., Rodríguez-Ariza, L. and Frías-Aceituno, J.V. (2013), "The cultural system and integrated reporting”, International Business Review, Vol. 22 No. 5, pp. 828-838.

33) Gelmini, L., Bavagnoli, F., Comoli, M. and Riva, P. (2015), "Waiting for materiality in 
the context of integrated reporting: theoretical challenges and preliminary empirical findings", in Songini, M. and Pistoni, A.M. (eds), Sustainability disclosure: state of the art and new directions, Bingley, Emerald Group Publishing Ltd, pp. 135-163.

34) Giovannoni, E. and Fabietti, G. (2013), "What is sustainability? A review of the concept and its applications", in Busco, C., Frigo, M.L., Riccaboni, A. and Quattrone, P. (eds), Integrated Reporting: Concepts and Cases that Redefine Corporate Accountability, Springer, London, pp. 21-40.

35) Granà, F. and Ceccacci, F. (2013), "The case of Eskom", in Busco, C., Frigo, M.L., Riccaboni, A. and Quattrone, P. (eds), Integrated Reporting: Concepts and Cases that Redefine Corporate Accountability, Springer, London, pp. 297-311.

36) Granà, F. and Mari, L.M. (2013), "The case of Vodacom Group", in Busco, C., Frigo, M.L., Riccaboni, A. and Quattrone, P. (eds), Integrated Reporting: Concepts and Cases that Redefine Corporate Accountability, Springer, London, pp. 237-253.

37) Gonzalbez, J.M. and Rodriguez, M.M. (2012), "XBRL and integrated reporting: the Spanish accounting association taxonomy approach", International Journal of Digital Accounting Research, Vol. 12 No. 18, pp. 59-91.

38) Haller, A. and van Staden, C. (2014), "The value added statement - an appropriate instrument for integrated reporting", Accounting, Auditing and Accountability Journal, Vol. 27 No. 7, pp. 1190-1216.

39) Hamid, F.Z.A., Shafie, R. and Othman, Z. (2015), "The "cognitive experience, area of business, responsiveness and engagement" conceptual framework for integrated reporting", Advanced Science Letters, Vol. 21 No. 6, pp. 1791-1793.

40) Higgins, C., Stubbs, W., Love, T. (2014), "Walking the talk(s): organisational narratives of integrated reporting", Accounting, Auditing and Accountability Journal, Vol. 27 No. 7, pp. 1090-1119.

41) James, M.L. (2013), "Sustainability and integrated reporting: a case exploring issues, benefits and challenges", Journal of the International Academy for Case Studies, Vol. 19 No. 8, pp. 89-96.

42) James, M.L. (2013), "Sustainability and integrated reporting: opportunities and strategies for small and midsize companies", Entrepreneurial Executive, Vol. 18, pp. 17-28.

43) James, M.L. (2015), "The benefits of sustainability and integrated reporting: an investigation of accounting majors' perceptions", Journal of Legal, Ethical and Regulatory Issues, Vol. 18, pp. 1-20.

44) Jensen, J.C. and Berg, N. (2012), "Determinants of traditional sustainability reporting versus integrated reporting. An institutionalist approach", Business Strategy and the Environment, Vol. 21 No. 5, pp. 299-316.

45) Kamp-Roelands, N. (2013), “A commentary on 'integrated reporting: a review of 
developments and their implications for the accounting curriculum'", Accounting Education, Vol. 22 No. 4, pp. 357-359.

46) Kaspina, R.G., Molotov, L.A. and Kaspin, L.E. (2015), "Cash flow forecasting as an element of integrated reporting: an empirical study", Asian Social Science, Vol. 11 No. 11, pp. 89-94.

47) Kuzina, R.W. (2014), "Integrated reporting as a mechanism of increasing business value", Actual Problems of Economics, Vol. 158, pp. 385-392.

48) Lambooy, T., Hordijk, R. and Bijveld, W. (2014), "Communicating about integrating sustainability in corporate strategy: motivations and regulatory environments of integrated reporting from a European and dutch perspective", Critical Studies on Corporate Responsibility, Governance and Sustainability, Vol. 6, pp. 217-255.

49) Lee, K.W. and Yeo, G.H.H. (2015), “The association between integrated reporting and firm valuation", Review of Quantitative Finance and Accounting, first online, pp. 1- 30.

50) Lodhia, S. (2014), "Exploring the transition to integrated reporting through a practice lens: an Australian customer owned bank perspective", Journal of Business Ethics, Vol. 129 No. 3, pp. 585-598.

51) Maniora, J. (2015), "Is integrated reporting really the superior mechanism for the integration of ethics into the core business model? An empirical analysis", Journal of Business Ethics, first online, pp. 1-32.

52) McNair-Connolly, C.J., Silvi, R. and Bartolini, M. (2013), "Integrated reporting and value-based cost management: a natural union”, in Busco, C., Frigo, M.L., Riccaboni, A. and Quattrone, P. (eds), Integrated Reporting: Concepts and Cases that Redefine Corporate Accountability, Springer, London, pp. 147-157.

53) Melloni, G. (2015), "Intellectual capital disclosure in integrated reporting: an impression management analysis”, Journal of Intellectual Capital, Vol. 16 No. 3, pp. 661-680.

54) Melloni, G., Stacchezzini, R. and Lai, A. (2015), "The tone of business model disclosure: an impression management analysis of the integrated reports", Journal of Management and Governance, first online, pp. 1-26.

55) Mio, C. (2013), "Materiality and assurance: building the link", in Busco, C., Frigo, M.L., Riccaboni, A. and Quattrone, P. (eds), Integrated Reporting: Concepts and Cases that Redefine Corporate Accountability, Springer, London, pp. 79-94.

56) Mio, C. and Fasan, M. (2013), "The case of Enel”, in Busco, C., Frigo, M.L., Riccaboni, A. and Quattrone, P. (eds), Integrated Reporting: Concepts and Cases that Redefine Corporate Accountability, Springer, London, pp. 225-236.

57) Owen, G. (2013), "Integrated reporting: a review of developments and their implications for the accounting curriculum", Accounting Education, Vol. 22 No. 4, pp. 340-356.

58) Owen, G. (2013), “A rejoinder to commentaries on 'integrated reporting: a review of 
developments and their implications for the accounting curriculum'", Accounting Education, Vol. 22 No. 4, pp. 363-365.

59) Paternostro, S. (2013), "The connectivity of information for the integrated reporting", in Busco, C., Frigo, M.L., Riccaboni, A. and Quattrone, P. (eds), Integrated Reporting: Concepts and Cases that Redefine Corporate Accountability, Springer, London, pp. 59-77.

60) Pistoni, A. and Songini, L. (2015), "New trends and directions in CSD: the integrated reporting", in Songini, M. and Pistoni, A.M. (eds), Sustainability disclosure: state of the art and new directions, Emerald Group Publishing Ltd., Bingley, pp. 81-105.

61) Quarchioni, S. and Trovarelli, F. (2013), "Approaching risk management from a new integrated perspective”, in Busco, C., Frigo, M.L., Riccaboni, A. and Quattrone, P. (eds), Integrated Reporting: Concepts and Cases that Redefine Corporate Accountability, Springer, London, pp. 159-170.

62) Rambaud, A. and Richard, J. (2015), "The "triple depreciation line" instead of the "triple bottom line": towards a genuine integrated reporting", Critical Perspectives on Accounting, Vol. 33, pp. 92-116.

63) Rensburg, R. and Botha, E. (2014), "Is integrated reporting the silver bullet of financial communication? A stakeholder perspective from South Africa”, Public Relations Review, Vol. 40 No. 2, pp. 144-152.

64) Reute, M. and Messner, M. (2015), "Lobbying on the integrated reporting framework: An analysis of comment letters to the 2011 discussion paper of the IIRC", Accounting, Auditing and Accountability Journal, Vol. 28 No. 3, pp. 365-402.

65) Rinaldi, L. (2013), “Stakeholder engagement”, in Busco, C., Frigo, M.L., Riccaboni, A. and Quattrone, P. (eds), Integrated Reporting: Concepts and Cases that Redefine Corporate Accountability, Springer, London, pp. 95-109.

66) Robertson, F.A. and Samy, M. (2015), "Factors affecting the diffusion of integrated reporting - a UK FTSE 100 perspective”, Sustainability Accounting, Management and Policy Journal, Vol. 6 No. 3, pp. 190-223.

67) Rowbottom, N. and Locke, J. (2015), "The emergence of $<\mathrm{IR}>$ ", Accounting and Business Research, first online, pp. 1-33.

68) Ruggiero, P. and Monfardini, P. (2013), "The case of HERA”, in Busco, C., Frigo, M.L., Riccaboni, A. and Quattrone, P. (eds), Integrated Reporting: Concepts and Cases that Redefine Corporate Accountability, Springer, London, pp. 313-330.

69) Setia, N., Abhayawansa, S., Joshi, M. and Huynh, A.V. (2015), "Integrated reporting in South Africa: some initial evidence", Sustainability Accounting, Management and Policy Journal, Vol. 6 No. 3, pp. 397-424.

70) Sierra-García, L., Zorio-Grima, A. and García-Benau, M.A. (2015), "Stakeholder engagement, corporate social responsibility and integrated reporting: an exploratory study", 


\section{Macrothink}

International Journal of Accounting and Financial Reporting

ISSN 2162-3082

2017, Vol. 7, No. 1

Corporate Social Responsibility and Environmental Management, Vol. 22 No. 5, pp. 286-304.

71) Siew, R.Y.J.R. (2015), "Briefing: integrated reporting - challenges in the construction industry", Proceedings of the Institution of Civil Engineers: Engineering Sustainability, Vol. 168 No. 1, pp. 3-6.

72) Simnett, R. and Huggins, A.L. (2015), "Integrated reporting and assurance: where can research add value?", Sustainability Accounting, Management and Policy Journal, Vol. 6 No. 3, pp. 29-53.

73) Smaldore, L.G. and Cavazzoni, C. (2013), "The case of Smithfield Foods", in Busco, C., Frigo, M.L., Riccaboni, A. and Quattrone, P. (eds), Integrated Reporting: Concepts and Cases that Redefine Corporate Accountability, Springer, London, pp. 255-274.

74) Soyka, P.A. (2013), “The International Integrated Reporting Council (IIRC) integrated reporting framework: toward better sustainability reporting and (way) beyond", Environmental Quality Management, Vol. 23 No. 2, pp. 1-14.

75) Steyn, M. (2014), “Organisational benefits and implementation challenges of mandatory integrated reporting: Perspectives of senior executives at South African listed companies", Sustainability Accounting, Management and Policy Journal, Vol. 5 No. 4, pp. 476-503.

76) Stubbs, W. and Higgins, C. (2014), "Integrated reporting and internal mechanisms of change", Accounting, Auditing and Accountability Journal, Vol. 27 No. 7, pp. 1068-1089.

77) Stubbs, W. and Higgins, C. (2015), “Stakeholders' perspectives on the role of regulatory reform in integrated reporting", Journal of Business Ethics, first online, pp. 1-20.

78) Thomson, I. (2015), “'But does sustainability need capitalism or an integrated report' a commentary on 'The International Integrated Reporting Council: A story of failure' by Flower, J.", Critical Perspectives on Accounting, Vol. 27, pp. 18-22.

79) Tweedie, D. and Martinov-Bennie, N. (2015), "Entitlements and time: integrated reporting's double-edged agenda", Social and Environmental Accountability Journal, Vol. 35 No. 1, pp. 49-61.

80) van Bommel, K. (2014), "Towards a legitimate compromise? An exploration of integrated reporting in the Netherlands", Accounting, Auditing and Accountability Journal, Vol. 27 No. 7, pp. 1157-1189.

81) Veltri, S. and Silvestri, A. (2015), "The Free State University integrated reporting: a critical consideration", Journal of Intellectual Capital, Vol. 16 No. 2, pp. 443-462.

82) Wulf, I., Niemöller, J. and Rentzsch, N. (2014), "Development toward integrated reporting, and its impact on corporate governance: a two-dimensional approach to accounting with reference to the German two-tier system", Journal of Management Control, Vol. 25 No. 2, pp. 135-164. 


\section{Macrothink \\ International Journal of Accounting and Financial Reporting \\ ISSN 2162-3082 \\ 2017, Vol. 7, No. 1}

Database: Google Schoolar (Books)

1) Eccles, R.G., Krzus, M. and Ribot, S. (2015), The integrated reporting movement: meaning, momentum, motives, and materiality, Wiley, Hoboken.

2) Eccles, R.G. and Krzus, M. (2010), One report: integrated reporting for a sustainable strategy, Wiley, Hoboken.

3) Loska, T. (2011), Integrated reporting. Towards a framework for a sustainable international corporate reporting, Grin Verlag GMBH.

4) Leicht, D. (2013), Integrated reporting of corporate financial and nonfinancial data: delivering on its promise to contribute to sustainable development? A critical analysis, Grin Verlag GMBH.

5) Adams, C.A. (2013), Understanding integrated reporting: the concise guide to integrated thinking and the future of corporate reporting, Do Sustainability, Oxford.

6) Kass, A. (2013), Towards mainstreaming integrated reporting - Theoretical landscape and practical insights, Grin Verlag GMBH.

7) Ligtenberg, D. (2013), Moving forward towards integrated reporting: a study on the level of disclosure on the content elements of the "IR" framework in the financial services industry, Grin Verlag GMBH.

\section{Copyright Disclaimer}

Copyright for this article is retained by the author(s), with first publication rights granted to the journal.

This is an open-access article distributed under the terms and conditions of the Creative Commons Attribution license (http://creativecommons.org/licenses/by/3.0/). 